\title{
Institutional Individualisation? The Family in European Social Security Institutions
}

\author{
PATRICIA FRERICKS*, JULIA HÖPPNER** AND RALF OCH*** \\ *Faculty of Social Sciences, University of Helsinki, Snellmaninkatu 10, Fl-00014 Helsinki, \\ Finland \\ email: patricia.frericks@helsinki.fi \\ ** Center for Globalisation and Governance, Hamburg University, Welckerstraße 8, D - 20354 \\ Hamburg, Germany \\ email: julia.hoeppner@wiso.uni-hamburg.de \\ *** Center for Globalisation and Governance, Hamburg University, Welckerstraße 8, \\ D - 20354 Hamburg, Germany \\ email: ralf.och@wiso.uni-hamburg.de
}

\begin{abstract}
Welfare institutions have long been set up in most European countries in ways oriented towards the family as the one basic principle. Reforms in recent times however have fundamentally changed the conception of the social citizen. Yet social rights are still mainly conceptualised in the literature in terms of employee rights, and family elements are often interpreted as a kind of vestige of the traditional welfare-state policies of industrial societies.

In this paper we develop a formula for making the weight of the family in social security visible and comparing it through the evaluation of cross-country levels of institutional individualisation. We deliver original theoretical, conceptual and empirical insights into the welfare-institutional order with the aim of furthering the understanding of the current social constitution of European societies. The findings show that there is considerable variation in the degree to which welfare institutions treat the social citizen as an individual and that the results do not correspond to common welfare categorisations.
\end{abstract}

\section{Introduction}

Institutions frame behaviour through sanctions that support or limit specific types of action. To this end, welfare institutions, and institutions in general, are based on certain principles that determine the provision of social security and social services. Different types of welfare states, so-called welfare regimes, link these social rights to various conditions depending on their basic principles. The differences in this social phenomenon are the focus of this paper. Welfare institutions have long been set up in most European countries in ways that take the family as the one guiding principle. Reforms, however, have now fundamentally changed the socio-political conception of the social citizen. Family elements in current welfare institutions are mainly interpreted as a kind of 
vestige of the traditional welfare-state policies of industrial societies. However, this interpretation overlooks the fact that various institutional regulations have recently been introduced or broadened in order to strengthen precisely the family elements in welfare institutions. The degree of individualisation, or the incorporation of family elements in social security systems, is an important condition for the attribution of social rights, and may result in very different forms of social inequalities and social risks. A systematic analysis of the extent to which citizens are now institutionalised as individuals, however, is lacking and forms the aim of this paper. Being original in concept, methods and empirical analysis, this study intends systematically to make visible and compare the relative weight of the family in European social security institutions. For this empirical analysis of institutional regulations, an ideal-typical model will be developed and adequate indicators identified.

\section{Institutional individualisation in European social security institutions}

Welfare regulations first appeared in the late nineteenth century and reached their most comprehensive form in the western European welfare institutions of the 1980 os. These welfare institutions aim to provide citizens with social security in particular life-course situations such as job loss or old age, and to provide social services to alleviate particular situations of everyday life (Esping-Andersen, 1990). Welfare institutions, continuously modified by social policies, determine the organisation, level of benefits and principles of social security. Our understanding of social rights can be traced back to Marshall's constitutive concept of democratic welfare capitalism, or welfare states (Marshall, 1950). Two of Marshall's conceptual elements are particularly relevant to this study. First, welfare states assign social rights to the married couple as a 'team'. Consequently, the unit of social rights is not the individual but the family, and social security is derived from the head of the family or household. Second, this concept differentiates between two levels of publicly institutionalised social security: the welfare-state target social security level, and the poverty prevention level. Both of these conceptual elements form part of all existing welfare states. After decades of reforms, however, the currently instituted concept of 'social rights' has never been systematically analysed, either for the different areas of social security within one welfare state, or in an international comparison.

Probably the most important function of welfare states has been signalled as 'decommodification'. Referring to Marx' criticism of workers' dependence on the market, Esping-Andersen (1990) defines social rights as decommodification, i.e. the state's guarantee of exemption from the coercion to sell one's own labour. The institutional setup of decommodification determines which citizens are exempt from labour-market participation and what levels of benefits they 
are entitled to during what phases of life. The concept of decommodification, however, derives from the concept of the state-market dichotomy and the classical vertical differentiation of workers. Horizontal differentiation (by age, migrationbackground or gender) is left aside (Korpi, 2010), as is the institutionalisation of the family. In the past, however, the various functions of the household and family were the essential rationales of welfare policies. Gender-specific lifecourses and activities based on a work-sharing family concept with women assigned non-paid work, particularly child- and elder care, were institutionalised with corresponding welfare entitlements, i.e. rights derived from the labourmarket status of the breadwinner. The manner and degree to which the institutional regulations on social rights incorporate the family differ both among countries and in historical comparison (Pfau-Effinger, 2004). Since the 1990s, however, the socio-political conception of the social citizen has undergone a fundamental change. It is the prevalent socio-political aim to 'activate' 'passive' social citizens in terms of individual labour-market participation in order to reduce governments' social expenditures and increase their international competitiveness. The corresponding concept on the European level, the 'social investment state', envisages integrating increasing numbers of the unemployed and 'non-active' into the labour market, an idea which closely resembles the 'adult worker model' (Daly, 2011) in which every 'able-bodied' adult participates in the labour market. As a result the individual seems to be increasingly less dependent on the family. Social security institutions have been reformed accordingly so that, in many ways, the importance of a male breadwinner is reduced: derived rights have been narrowed and partly abandoned (partner allowance, widow(er)s' entitlements); levels of social security benefits have been lowered and consequently are no longer designed to provide security for the family; and social security systems are increasingly oriented towards continuous and individual labour-market participation (Gilbert and Van Voorhis, 2003). One of the most important elements in the new concept of the social citizen, in terms of social rights, is the individual, labour market-'activated' and 'self-responsible' social citizen (Nullmeier, 2006). Regulations dealing with social security eligibility that do not correspond to this individualised 'citizen-the-wage-earner' (Lister, 2003) are, in line with the idea of modernisation, partly interpreted as a remnant of formerly familialised regulations (Esping-Andersen et al., 2002). Recent research shows however that the concept of an individualised social citizen has not been comprehensively implemented anywhere, and the degree of implementation varies from country to country (Daly, 2011; Leitner, 2003). For instance, no European country has a fully individualised tax system. In addition, it has been demonstrated that it is the calculation of social entitlements that is increasingly based on the individual while, at the same time, new family-related elements of social rights have been implemented such as pension entitlements derived from caring for children or elders (Blome et al., 2009; Frericks, 2013). How the 
concrete design of entitlements to social rights differs in this respect, however, has not been analysed systematically. Socio-political appeals to family solidarity in times of need form part of this development. To generally interpret means-tests as typically characteristic family-related elements of social security however as most social policy analyses do - is not adequate in terms of addressing the complexity of actual regulations, since family-related elements of social security are not limited to means-tested social rights.

To compare welfare states and comprehend their differences, a variety of typologies for international comparative analyses have been developed. The most influential among them is the typology of welfare regimes by Esping-Andersen (1990) which originally differentiated three types of welfare regime. This typology is highly suitable for an international comparison since it allows examination of the differences in organisation, structure and basic principles of welfare states; analysis of the effects of the various indicators on social inequality, and explanation of these differences. The dimensions of state, market and family are those used to distinguish the main responsibilities in providing social security and social services. However, the degree of decommodification is measured by means of employee rights, not social rights, and the dimensions of this typology are not adequate to analyse welfare states' concepts of the social citizen since they do not identify the degree of individualisation of the social citizen. Feminist researchers have developed approaches to differentiate gender regimes and to compare losses of social rights related to the various care activities of women, which depend on how social rights are linked to labour-market participation (Lister, 2003). The analysis of welfare-state institutional individualisation, however, is restricted to family policies and social services, as is also the case in many empirical studies (Daly and Scheiwe, 2010; Saraceno and Keck, 2010). The most important contribution in comparing the family in welfare states focuses on the welfare-mix and the 'caring function of the family', of the state and of the market (Leitner, 2003: 353; also Saraceno and Keck, 2010). Here, however, we aim to analyse the degree of individualisation of the social citizen in social security systems which is not restricted to care or financial obligations. In addition, most welfare-state analyses (Bradshaw and Holmes, 2013; Esping-Andersen, 1990; Saraceno and Keck, 2010) examine welfare regulations by means of outcome data. Here, in contrast, we deliver a purely institutional analysis. Therefore, although various typologies of welfare states make it possible to systematically compare welfare policies and institutions and their impact on social rights, what is still lacking is a typology and a systematic comparative analysis of the differences in welfare states' regulation of social security eligibility with regard to the degree of individualisation criteria they manifest.

With this paper we want to contribute to filling the research gap on welfareinstitutional framing of the degree of individualisation of social rights. It will analyse below questions of the degree to which the family forms part of the 
concept of social citizenship: which family members are incorporated and at what levels of social security. The focus is therefore on welfare regulations with regard to the institutionalised degree of individualisation of the social citizen. The assumption, based on the state of the art as outlined above, is that the degree of individualisation of the social citizen, as framed by welfare institutions, differs widely between countries, and that the results demand a better differentiation of regime types with respect to the degree of individualisation. This assumption is based on the fact that existing regime typologies have not made it possible to analyse the degree of individualisation of the social citizen implied by welfare regulations. It is also assumed that welfare regulations differ within a country, in part since social security provision for old age may differ fundamentally from that for unemployment, again with regard to the degree of individualisation.

\section{Methodology and approach}

Below we empirically analyse the degree of individualisation of the social citizen in welfare institutions. The aim is to systematically gather and internationally compare the study countries' complex welfare-institutional social security setups with regard to their conception of social rights as related to the individual or the family. We analyse here the welfare institutions of 2013 , since data for 2014 are less comprehensive. We analyse two different areas of social protection meant to support the social citizen during two important periods in life in which s/he is not participating in the labour market: social security in old age and social security in times of unemployment. Other welfare areas with their regulations that conceptualise the social citizen either as an individual or as a family member (e.g. tax systems, social services and health insurance) are not part of this systematic analysis since they depend on additional components, involve different objectives, and would need to be analysed by very different indicators. The degree of institutional individualisation will be analysed separately for both institutionalised social security levels: first, the 'target social security level' (TSSL); and, second, the 'poverty prevention level' (PPL). The further conceptual development of the Marshallian TSSL is taken from Frericks (2013), who defines it as the institutionalised and nationally defined target level for social protection in the form of the benefit calculation norm. This is not a guaranteed or a factual benefit level, but the national point of reference for benefits to be reached by the 'average' citizen or, as Frericks put it, it 'serves as a conceptual tool to analyse institutional functioning (with regard to the institutional aims)' (Frericks, 2013: 670 ). In pensions, this level is mainly called 'full pensions'. We analyse both of the institutional benefit levels since we assume variation between them. We compare ten European countries: Denmark, Estonia, the UK, Italy, Sweden, Spain, the Czech Republic, Hungary, Germany and France. The choice of countries is based on the welfare-regime approach proposed by Esping-Andersen and its further 
development. Our aim is to gain a more profound knowledge of the welfare states' framing of social citizens and thereby to challenge the classical clustering of welfare regimes. The analysis examines the degree of individualisation of social citizens in a welfare state's social security, respectively the degree of family elements in it. The neutral term 'family elements' comprises both the institutional expectation of family solidarity in terms of subsidiarity (e.g. when the income of family members is included in the calculation of means-tested benefits) and the recognition of social entitlements based on family characteristics (e.g. pension benefits for having children). Our results, therefore, do not show the factual increase or loss in social rights, but the degree to which family forms part of the calculation formula of benefits. The focus is on public social security systems and does not include welfare markets.

We develop and apply a theory-driven typology that helps us to understand conceptually and grasp empirically the degree of welfare-institutional individualisation. This typology corresponds to Weberian ideal types developed as a heuristic instrument of sociological analysis and the systematisation of empirical historic reality. The ideal-type approach is based on the establishment of clear-cut terms to analytically and unequivocally comprehend reality (Weber, 1973). By means of establishing four ideal-type reference points as corner marks, a 'space of characteristics' (Schnell et al., 2005: 168) is formed within which the study countries' degree of individualisation in social security is positioned. The following ideal-typical corner marks are sufficient to locate the degree of individualisation of a country's social citizen in terms of social rights: (1) individualised; (2) linked to the partner; (3) generationally linked; and (4) linked to other family members. We operationalise the term 'generation' as the analysed social citizen and his/her children, i.e. the nuclear family, while other generational links are operationalised in the family dimension 'other family members' (see Walker, 2005).

The empirical data on the study countries' welfare institutions is then fed into this typology. To this end, we first identify the relevant indicators. We do this by identifying all the family elements that form an explicit part of these social security institutions. We then assess them in the context of the calculation of a 'full' pension or unemployment benefits. We take into account institutional regulations affecting the financial implications, the conditionality of the entitlements and the criteria that serve to calculate the benefits. Regulations generally stemming from other than the specified welfare institutions (e.g. longterm care or housing regulations) are not analysed here. On TSSL for old age, we apply values that are calculated on the basis of the nationally defined calculation of ('full') pension rights. To identify the degree of individualisation, one needs to take into account the most relevant 'footnotes' to the calculation formulae, since in general they contain the family elements that put the seemingly individualised formula into perspective. The values indicate the degree to which family elements 
might form part of the benefit calculation. This is also the case for TSSL in unemployment, the difference being that benefit rights related to unemployment refer to much shorter time periods, and family elements add to the original TSSL. Rights based on family elements are interpreted here as surplus to the TSSL, while in pensions they are interpreted as a substitute for other conditions (labour-market participation in particular) in order to build up 'full' rights. This difference is caused by the different concepts of social rights in these policy areas. The weight and conception of the family elements differ per country and area and therefore need case-specific deduction, i.e. the indicators are quantified within the national calculation norm for the respective right. On PPL, the welfare states determine which family members have to support the unemployed or the pensioner and the proportion of their income and/or assets that serve to cover the living costs of the claimant before being entitled to state benefits. The higher this amount the stronger the family element.

To enter the empirical insights into the typology, the qualitative data is quantified onto ordinal scales. The degree of individualisation ranges from o to 1 in ten gradations. While zero refers to ideal-typical individualisation, a value of 1 indicates that a full pension can be reached entirely by family elements or twice the unemployment benefit (on TSSL) or that a (certain type of) family member carries the full responsibility to maintain the social citizen (on PPL). In the case where regulations set additional conditions besides family as status and therewith bring the family element into perspective - i.e. the ideal-typical corner marks cannot be reached - we weight the indicators by two-thirds for each additional condition. Such additional conditions are, for instance, the boundary of the household, which limits the rights and obligations of family members to those who live in the same household, or activities including caring for family members. Below we give the case-specific and weighted values for the indicators (a comprehensive database containing the calculation of each single indicator can be provided on demand). In addition, if an indicator refers to the number of family members we multiply the value by 2 and, in cases where the calculation differentiates between one or more family members, we multiply it by 1.5 . To make the differences between the countries more clear, we show the indicator values up to two places after the decimal point. We illustrate our calculation with a straightforward example: for the Spanish TSSL in unemployment, the existence of children increases the benefits of the unemployed by, taking the (institutionally inscribed) mean, 31 per cent. Within the calculation logic of this institution, this family element corresponds to an indicator value of 0.31 . However, since children are considered only if dependent, there is an additional condition, which weights the value by two-thirds (0.21). Since the calculation differs in case of one or more children we multiply the value by 1.5 . The weighted value for this indicator is therefore 0.32. The weighted values of the single indicators will then be added in order to get a single value for each family dimension (partner, generation, 
others). However, if two regulations are mutually exclusive, the values of the single indicators cannot be added. In such a case, we compute the mean of the two indicators. We identify thereby the coordinates of individualisation within the space of characteristics. The summarised values for each dimension are rounded to one digit after the decimal point.

This codification allows a nuanced identification of the welfare-institutional individualisation of the social citizen. Since the degree of individualisation is measured separately on the three family dimensions for two levels of social security and two policy areas, each country is given the coordinates of four reference points within the 'space of individualisation' of welfare institutions. These coordinates in turn help us identify country-cluster formations and variation in the degree of individualisation with regard to the areas and levels of social security and the corresponding family dimension.

In the following section we analyse the degree to which welfare institutions contain elements that treat the social citizen as a family member. Literature, documents and regulative data were analysed to identify the specific characteristics of welfare institutions in the ten countries with regard to the research questions. The data for the analysis are mainly based on the Mutual Information System on Social Protection database (MISSOC, 2014) and the International Social Security Association (ISSA, 2014), since sources on current regulations with regard to individualisation are very limited. Other data used are identified.

\section{Analysis}

\subsection{Family elements in old-age security}

The aim of this part is to illustrate the degree to which old-age security institutions contain elements that treat the social citizen as an individual, or as a family member.

\section{Target social security level}

On TSSL, old-age security institutions differ considerably. In all countries, 'full' pensions in the sense of meeting the TSSL depend on some general conditions which include a particular number of years (and level of contributions) in employment which, in some countries, might be partly substituted by derived rights or other pension-valued activities (e.g. apprenticeship/study, care). The indicators for our analysis are the family elements that form part of the pension calculation. On the dimension of partnership these are regulations concerning the splitting of pension entitlements between (married) partners, and pension benefits for having a partner or spouse. Survivor pension for retirement-age survivors is another indicator, since it becomes the survivor's own pension right in addition to the pension entitlements that he/she built up him/herself and 
possibly adds up to TSSL. Also, pension entitlements for caring for a frail partner are analysed. Indicators for the dimension of generation are, first of all, pension entitlements for having or having cared for children. Survivor pensions and rights deriving from care activities on behalf of frail relatives are relevant to the dimension of 'other family members'.

On the partner dimension we find the following family elements. In Germany, there is a regulation to split pension entitlements between spouses. It offers the opportunity for both spouses with different pension levels to build up 'full' pensions in the sense of TSSL. Only spouses who married after 2001 are eligible and each must have at least 25 years of insurance. In the case of divorce, each of the spouses receives 50 per cent of the pension entitlements of the ex-partner that were acquired during the time of marriage if nothing is otherwise agreed between them (the mean of both indicators is 0.20 ). In the UK, a pensioner's dependent spouse can receive 60 per cent of the Basic State Pension when he or she reaches pension age (0.31). In the other countries there are no regulations concerning pension entitlements for a spouse or a partner (0.0).

In all countries there is some kind of survivor pension; however, in Sweden (o.o) it is provided only to people under retirement age and therefore does not form part of old-age security. In Estonia (o.o) the survivor pension cannot be combined with other state pensions and is therefore not relevant in this context (State Pension Insurance Act). In the other countries, 25-70 per cent of the pension of the deceased person is paid to the surviving spouse or partner; in a few cases a lump sum is paid. The value of the survivor pension in TSSL, depending on this percentage, differs as follows: Denmark (0.03), Italy (0.27), Spain (0.35), Czech Republic (0.40), Hungary (0.20), Germany (0.25), France (0.25) and UK (0.40).

As to entitlements for care of frail spouses or partners, the study countries strongly differ. Sweden is rated at zero because it does not offer any such entitlements. Spain (0.02) and Hungary (0.06) offer very low pension entitlements to caring family members on the basis of short qualifying periods, i.e. periods that have only an indirect influence on the calculation of pension entitlements. France (o.14), Germany (o.16), Estonia (0.18), UK and Czech Republic (both 0.30) offer higher entitlements in addition to direct financial entitlements. Denmark is ranked 0.44 because caring family members can be employed as municipal employees with full social security under certain conditions (Frericks et al., 2014).

Summing up the indicator values, the case-sensitive and weighted quantification suggests the following rounded values for the degree of individualisation for the overall calculation of pensions on the dimension of partners: zero for Sweden, 0.2 for Estonia, 0.3 for Hungary and Italy, 0.4 for France and Spain, 0.5 for Denmark, 0.6 for Germany and 0.7 for the Czech Republic and UK. 
On the dimension of generation we find the following family elements. In all our study countries pension entitlements are accorded, though to differing degrees, for child rearing. With regard to qualifying periods, as well as financial entitlements, in pension calculations for child rearing, Denmark (0.02), Italy ${ }^{1}$ (0.05), Spain (0.09) and Hungary (0.09), are all rated up to 0.1 because they all provide very limited or mainly time-based entitlements for child rearing. In Estonia (0.12) and Czech Republic (0.19) parents can retire a bit earlier depending on their number of children (Republic of Estonia, 2014). Sweden (o.18), France (o.17) and the UK (o.17) offer some financial entitlements and/or longer qualifying periods for maternity and parental leave, while Germany (o.21) has the most generous regulations, of which the most important are independent of work interruptions. Moreover, Hungary (o.13) provides a survivor pension for parents. Italy, Spain and Estonia also provide such survivor pensions, but these pensions do not help to reach TSSL.

To sum up, the rounded values for the dimension of generation are zero for Denmark, 0.1 for Italy, Estonia and Spain and 0.2 for Hungary, Czech Republic, France, the UK, Sweden and Germany.

Also with regard to other family members, the degree of family elements differs between the countries. In none of them does status confer pension rights on other family members. They are all rated at zero in this regard. Apart from Sweden (o.o), there are pension entitlements for care of frail relatives. Spain (0.02) and Hungary (0.06) offer only short qualifying periods for caring family members. Germany (o.16), France (o.14), Estonia (o.18), the Czech Republic and UK (o.30) (Age UK, 2014) and Denmark (0.44) offer longer qualifying periods and financial entitlements.

Rights in the form of survivor pensions for other family members are practically negligible: In Hungary (o.13), siblings of deceased insured persons can receive a quite generous survivor pension under well-specified conditions. All other countries are rated at zero.

Summing up, we rate family elements for persons other than partners or children as follows: zero for Spain, Italy and Sweden, 0.1 for France, 0.2 for Estonia, Hungary and Germany, 0.3 for the Czech Republic and UK, and 0.4 for Denmark.

One important result with regard to TSSL for old age is that it is important to differentiate the family dimensions since countries strongly differ in this respect. By the level of individualisation on the family dimensions, we can classify the countries into three groups: Sweden (0.0/0.2/0.0), Estonia (0.2/0.1/0.2), Italy (0.3/o.1/o.o) and Hungary (0.3/o.2/o.2) show rather low family elements on all dimensions. In a number of countries there is a high level of family elements on the partner dimension, but rather fewer and low family elements on the other two dimensions. These are the Czech Republic and UK (both 0.7/0.2/0.3), Germany (0.6/0.2/0.2) and, less pronounced, Spain (0.4/0.1/0.0) and France 
(0.4/0.2/0.1). Lastly, Denmark (0.5/0.0/0.4) shows considerable family elements on the dimension of the partner and other family members, but none on the generation dimension. ${ }^{2}$

\section{Level of poverty prevention}

At PPL in old age, the ten countries differ more than they do at TSSL. The main indicator that we consider here is the means-test. ${ }^{3}$

On the partner dimension we find the following family elements. In all countries, the income and/or assets of spouses or partners are taken into account in defining entitlements to poverty-preventing pensions. In Sweden, Denmark and Estonia there is no family-based means-test in relation to the minimum pension. In Denmark (0.06) the minimum pension consists of a basic amount and a means-tested pension supplement which depends on the combined earnings of the pensioner and his/her spouse. In Spain (0.20), Italy (0.23), France (0.40), Germany (0.44), UK (0.47), Czech Republic (0.50) and Hungary (0.54) the income of the spouse or partner is taken into consideration to a varying degree.

The rounded values are thus o.o for Estonia and Sweden, o.1 for Denmark, 0.2 for Spain and Italy, 0.4 for France and Germany and 0.5 for the UK, Czech Republic and Hungary.

On the dimension of generation, Denmark, Italy, Sweden, Estonia, UK and Hungary show no family elements because neither income nor assets of children are taken into consideration (o.o). In Germany (o.10) the income of children is only taken into account when their annual gross income exceeds one-hundred thousand euros. In Spain (o.20), France (0.40) and the Czech Republic (0.50) the income of children as well as their assets are taken into consideration in large part. However, the regulation is applied only if the children are living in the same household as the applicant. There is no need to sum up or round the values.

In some countries the income and assets of other family members are also taken into account. Other family members are strongly taken into consideration in the Czech Republic (0.50), France (0.40) and Spain (0.20), though this is restricted to household members. In the other seven countries, there are no regulations concerning other family members (o.o).

To sum up, old-age regulations regarding PPL across the study countries include family elements to different degrees. On PPL, Sweden and Estonia (both 0.0/0.0/0.0) are completely individualised, while Denmark (0.1/0.0/0.0) and Italy (0.2/0.0/o.o) show low levels of partner elements. Furthermore, Spain (0.2/o.2/o.2), France (0.4/0.4/o.4) and Czech Republic (0.5/0.5/0.5) are three countries with identical degrees of family elements on all dimensions and, apart from Spain, these are relatively strong. Germany (0.4/0.1/0.0), the UK and Hungary (both 0.5/0.0/0.0) put emphasis on the dimension of the partner. Table 1 summarises the results. 
TABLE 1. Degree of individualisation at TSSL and PPL in old-age and unemployment security in ten European countries

\begin{tabular}{|c|c|c|c|c|c|c|c|c|c|c|c|c|}
\hline \multirow[b]{3}{*}{ Country } & \multicolumn{6}{|c|}{ Old-age security } & \multicolumn{6}{|c|}{ Unemployment security } \\
\hline & \multicolumn{3}{|c|}{ TSSL } & \multicolumn{3}{|c|}{ PPL } & \multicolumn{3}{|c|}{ TSSL } & \multicolumn{3}{|c|}{ PPL } \\
\hline & Partner & $\begin{array}{l}\text { Gene- } \\
\text { ration }\end{array}$ & $\begin{array}{l}\text { Other } \\
\text { family } \\
\text { members }\end{array}$ & Partner & $\begin{array}{l}\text { Gene- } \\
\text { ration }\end{array}$ & $\begin{array}{l}\text { Other } \\
\text { family } \\
\text { members }\end{array}$ & Partner & $\begin{array}{l}\text { Gene- } \\
\text { ration }\end{array}$ & $\begin{array}{l}\text { Other } \\
\text { family } \\
\text { members }\end{array}$ & Partner & $\begin{array}{l}\text { Gene- } \\
\text { ration }\end{array}$ & $\begin{array}{l}\text { Other } \\
\text { family } \\
\text { members }\end{array}$ \\
\hline $\mathrm{CZ}$ & 0.7 & 0.2 & 0.3 & 0.5 & 0.5 & 0.5 & 0.0 & 0.0 & 0.0 & 0.8 & 0.8 & 0.4 \\
\hline DK & 0.5 & 0.0 & 0.4 & 0.1 & 0.0 & 0.0 & 0.0 & 0.0 & 0.0 & 0.4 & 0.0 & 0.0 \\
\hline $\mathrm{EE}$ & 0.2 & 0.1 & 0.2 & 0.0 & 0.0 & 0.0 & 0.0 & 0.0 & 0.0 & 0.4 & 0.4 & 0.4 \\
\hline FR & 0.4 & 0.2 & 0.1 & 0.4 & 0.4 & 0.4 & 0.0 & 0.0 & 0.0 & 0.4 & 0.4 & 0.0 \\
\hline DE & 0.6 & 0.2 & 0.2 & 0.4 & 0.1 & 0.0 & 0.0 & 0.1 & 0.0 & 0.6 & 0.4 & 0.4 \\
\hline UK & 0.7 & 0.2 & 0.3 & 0.5 & 0.0 & 0.0 & 0.0 & 0.0 & 0.0 & 0.8 & 0.3 & 0.2 \\
\hline $\mathrm{HU}$ & 0.3 & 0.2 & 0.2 & 0.5 & 0.0 & 0.0 & 0.0 & 0.0 & 0.0 & 0.6 & 0.7 & 0.0 \\
\hline IT & 0.3 & 0.1 & 0.0 & 0.2 & 0.0 & 0.0 & 0.0 & 0.0 & 0.0 & - & - & - \\
\hline ES & 0.4 & 0.1 & 0.0 & 0.2 & 0.2 & 0.2 & 0.0 & 0.3 & 0.0 & 0.3 & 0.3 & 0.0 \\
\hline SE & 0.0 & 0.2 & 0.0 & 0.0 & 0.0 & 0.0 & 0.0 & 0.2 & 0.0 & 0.4 & 0.0 & 0.0 \\
\hline
\end{tabular}




\subsection{Family elements in unemployment security}

This part analyses the degree to which unemployment systems treat the unemployed as a family member or as an individual. Unlike pension regulations, unemployment regulations less often contain family elements with regard to TSSL but they do so more with regard to PPL. Also in unemployment regulations we observe strong variation in the degree of individualisation.

\section{Target social security level}

Unemployment benefits with regard to TSSL are by and large individualised. An overview on the schemes analysed is provided in the supplementary material available online.

On the partner dimension, in none of our countries (o.o) do unemployment benefits at TSSL make any reference to the partner of the unemployed person.

Family members in terms of the generation are, in some cases, considered in the calculation. In Germany benefits rise from 60 per cent of the last net income to 67 per cent if the beneficiary has at least one child. Since this difference is rather small and not differentiated by the number of children, the German system contains only minor family elements in this dimension (o.08). In Spain (0.31) benefits are differentiated as to the number of dependent children and increase by a mean of 31 per cent. In Sweden (0.15) having a child does not increase the benefits but it may prolong the maximum duration of receiving them from 300 to 450 days. All other countries are rated at zero on this dimension.

In none of the countries do unemployment benefits refer to other family members of the unemployed. Thus, all countries are rated at zero on this family dimension.

Summing up, there are two groups of countries at TSSL of unemployment systems. The first consists of Denmark, Estonia, the UK, Italy, Czech Republic, Hungary and France (all o.o/o.o/o.o) with no family elements whatsoever. Spain (0.0/0.3/o.o), Germany (0.0/0.1/o.o) and Sweden (o.o/o.2/o.o) have no family elements on the dimensions of the partner or other family members, and lowlevel ones on the dimension of the generation.

\section{Level of poverty prevention}

In the following we analyse the extent to which welfare states treat the unemployed in need as an individual or as a family member. In addition to the means-test, which is also applied to old-age PPL, the provision of care to family members might influence the benefits. Since there is no national unemployment regulation at PPL in Italy, it is not analysed here.

The degree of individualisation on the dimension of the partner regarding the means-test is as follows. Spain (o.33) is the only country considering income only. All the other countries take income and assets of the partner into account. In Denmark (o.38) only married partners are obliged to support the unemployed. 
Germany (0.27) has considerable exemptions for all members of the 'needs unit' (Bedarfsgemeinschaft). Sweden (0.36) has in general rather stringent means-test criteria, but if the need is considered temporary, they are not applied. France (o.39) evaluates the lifestyle of the family members against their means, resulting in rather strict conditions on personal assets and rather generous exemptions for the out-of-work partner's income. Estonia (0.26) provides an individualised but time-limited unemployment assistance after which the means-tested subsistence benefit steps in. In the Czech Republic (0.40), Hungary (0.57), and UK ${ }^{4}$ (0.49) there are rather few exemptions with regard to assets and income of the partner.

In some of our study countries, also caring for a partner affects the benefits of the unemployed. In none are benefits increased but the conditions for receiving them is altered. In the Czech Republic (0.44) caring for a care-dependent or temporarily ill partner suspends the obligation of the unemployed to look for employment. This is also the case in Germany (0.30), but under stricter conditions. In the UK (0.30) the caring unemployed must still be available for work at least $16 \mathrm{hrs} /$ week. Estonia (0.15) explicitly excludes the combination of caring for a family member and being registered as unemployed, but allows access to the unemployment allowance after having cared for a relative.

In short, we identify four groups: Spain (o.3); Denmark, Estonia, Sweden and France (all 0.4); Germany and Hungary (o.6); the UK and the Czech Republic (o.8).

On the dimension of generation, four of our countries apply the same conditions to the means-test for partners and for children, and they are assessed as above: Estonia (0.26), Spain (0.33), France (0.39), Czech Republic (0.40). In five countries the conditions of the means-test for children differ from those for adult family members: in the UK (0.08) the income counts under certain circumstances only, in Germany (0.12) the means of children are considered only if they form an economic unit with their parents, ${ }^{5}$ and in Hungary (0.32) only the means of dependent children are taken into consideration. In Denmark and Sweden (both o.o) children's means are not considered at all.

With regard to care, the Czech Republic, Germany, UK and Hungary reduce the obligation of the unemployed to look for employment when caring for (dependent) children: in the UK (0.30), in Germany (0.30) up to the age of three if there is no public care available, and in the Czech Republic (o.44) up to four years. In Hungary (o.39) the unemployed may care for a child up to age 14 if care at a day-care institution is not guaranteed. Moreover, since caring for a child in Hungary means that the unemployed person is not able to work, they are entitled to benefits from the regular social assistance (at 90 per cent instead of the 80 per cent of the minimum old-age pension ${ }^{6}$ ). As on the partnership dimension, Estonia (0.15) allows access to unemployment allowance after having cared for a relative. All other countries are rated at zero. 
The findings of this dimension are that Denmark and Sweden show the highest degree of individualisation (0.0) followed by Spain and the UK (0.3), Estonia, France and Germany (o.4). Hungary (0.7) and the Czech Republic (0.8) show very strong family elements.

The means of other family members in calculating the entitlements of the unemployed are considered in two of our countries. In Estonia (0.26) the conditions are the same as they are with regard to the partner. In Germany (o.10) all family members who form an economic unit with the social citizen are included. The other countries do not consider other family members' means (o.o).

In the Czech Republic caring for a frail family member (0.44) reduces the obligation of the unemployed to look for employment. This is also the case in Germany (0.30), but only when care cannot be arranged otherwise, and in the UK (0.20) to a lesser extent (Donegan et al., 2013). As on the other dimensions, Estonia (0.15) allows access to unemployment allowance.

In short, five countries (Denmark, Sweden, France, Spain and Hungary) do not consider other family members, either in terms of means or care. They are considered to differing degrees in the UK (o.2), and in Estonia, Germany and the Czech Republic (0.4).

Summing up, unemployment regulations at PPL across the study countries include family elements to different degrees. Differences occur in whether the countries include other family members in calculating the entitlements of the unemployed (Czech Republic, Estonia, Germany, Spain and UK). Regarding the degree of individualisation, we find three groups of countries. The first shows considerable family elements on the partner dimension but none on the other ones (Denmark and Sweden both 0.4/o.o/o.o). The second group shows considerable family elements on the partner and generational dimension but none on the 'other family' dimension (Spain 0.3/0.3/0.0, France 0.4/0.4/0.0 and Hungary $0.6 / 0.7 / 0.0)$. The third group shows family elements on all dimensions to varying degrees: Czech Republic (0.8/o.8/o.4), Estonia (0.4/0.4/o.4), Germany (o.6/0.4/0.4), and the UK (0.8/0.4/0.2).

\section{Discussion and conclusion}

This study analysed the degree to which social citizens are treated as individuals by welfare institutions. We conceptualised and measured individualisation by the degree to which welfare institutions link entitlements to social rights to the family. We differentiated three dimensions of family: partners, generation and other family members, assuming that welfare regulations differ with regard to them, and indeed, they strongly do. We also differentiated two institutional levels of social security: the target social security level (TSSL) and the level of poverty prevention (PPL). Again, we correctly assumed that welfare regulations differ in regard to these as well. 
A major result of this research is that, in all the ten countries of our study, there are regulations that take family members into account, both at TSSL and at PPL. The number and strength of the family elements in them, however, differ.

Within the single welfare states studied there are, as assumed, considerable differences in the degree of individualisation in social security systems. First of all, the degree of individualisation differs fundamentally between the two social security levels. The degree to which welfare institutions link entitlements to social rights to the family is the lowest at TSSL of unemployment regulations, while the highest values are to be found at PPL of unemployment regulations. ${ }^{7}$ In addition, the degree of individualisation differs greatly between the two policy areas. While family elements are negligible in unemployment security, in particular at TSSL, family elements are quasi area-wide within old-age security. Finally, there are in most cases considerable differences between the family dimensions within a policy field or security level, with the exception of TSSL in unemployment systems. To sum up, the findings show strong variation in parts of each single welfare state (see Table 1). Some similarity in the degree of individualisation can be observed on TSSL in Sweden, or respectively on PPL in France and in those regarding unemployment in Spain. The strong in-country variation in the design of welfare institutions is the first empirical result of our study.

In international comparison, the degree of individualisation takes on, as assumed, very different shapes. Similarities within the four single areas of analysis (the two policy areas and the two social security levels) are summed up after each respective analysis. Similarities that go beyond those can be found on the partner dimension in Germany and the UK, or on the generation dimension in the UK, Germany and Estonia. In any case - and this is the second empirical finding of our study - the results do not systematically correspond to Esping-Andersen's welfare regime typology. Germany and France, for example, differ in the degree of family elements, as do Italy and Spain, and also Denmark and Sweden show considerable differences. The most individualised systems are to be found in Italy, Sweden and Denmark, and the least individualised one is that of the Czech Republic. As a matter of course, individualisation might be a hidden expectation of family solidarity (Saraceno and Keck, 2010); this paper, however, analysed the institutionalised degree of it.

These results confirm our assumption that individualisation cannot be observed for the policy areas and social security levels we analysed. Differences in the conceptualisation of the social citizen - as an individual or as a family member - will remain crucial to an understanding of the differences in the regulating principles of welfare states and their redistributing effects. We have analysed family elements both in the sense of the institutionally expected family solidarity and in the sense of additional entitlements derived from family members, in order to measure the degree to which family elements are to be found in social security systems. There are other ways to comprehend the family in welfare-state 
institutions, one of which is to differentiate between rights and obligations. Our study shows that strong family elements at the TSSL, and low-level ones at PPL correspond to a high level of generosity of social rights towards the family. This is because family elements at PPL are related to means-testing in particular, and thereby correspond to financial obligations of the family. Conversely, a low degree of family elements at TSSL and a high one at PPL represents low welfare-state generosity towards the family and a distinct expectation of family solidarity. This differentiation allows us to see that some countries are generous towards the family and strongly expect family solidarity (Germany, France, Czech Republic, the UK and Hungary), while others refrain from both (this is most pronounced in Sweden and Italy).

\section{Supplementary material}

To view supplementary material for this article, please visit http://dx.doi.org/ 10.1017/So047279416000404

\section{Acknowledgements}

This paper is a result of the research project INDIV (Individualization of the social citizen in the welfare state: development and contradictions in Europe) which is generously financed by the Fritz Thyssen Foundation. We are thankful also to the University of Hamburg and its Center for Globalisation and Governance (CGG) for hosting and supporting this project. Furthermore, we very much appreciated the reviewers' comments and suggestions, and other colleagues' positive and encouraging reaction, in particular that of Birgit Pfau-Effinger.

\section{Notes}

1 In Italy, the coefficient used to calculate pensions is slightly advantageous for mothers (INPS, 2014).

2 Our decision not to include care of handicapped children in the calculation (as indicated in part three) was based on criteria of conceptual focus and methodological comparability.

3 Needs tests are not taken into account since the institutions assume here that the additional entitlements serve the needs of family member and not just those of the claimant him/herself.

4 In 2013 'universal credit' started to replace the income-based 'jobseekers allowance'. By the end of 2013, however, it had been implemented in only a few local authorities. We therefore do not include it here (see https://www.gov.uk/universal-credit).

5 In Germany, the economic unit consists of all people living in the same household but only if they are pooling income and/or expenses.

6 In Hungary the need of beneficiaries of social assistance and minimum unemployment benefit is calculated as a share of the minimum old-age pension.

7 When comparing the degree of family elements, one needs to keep in mind the point of reference which is the social right as provided in the different policy fields and levels.

\section{References}

Age, UK (2014), Advice for Carers, http://www.ageuk.org.uk/Documents/EN-GB/Informationguides/AgeUKIG13_Advice_for_carers_inf.pdf?dtrk=true (accessed 11 February 2016). 
Blome, A., Keck, W. and Alber, J. (2009), Family and the Welfare State in Europe. Intergenerational Relations in Ageing Societies, Cheltenham: Edward Elgar.

Bradshaw, J. and Holmes, J. (2013), 'An Analysis of Equity in Redistribution to the Retired and Children over Recent Decades in the OECD and UK', Journal of Social Policy, 42, 1, 39-56.

Daly, M. (2011), 'What Adult Worker Model? A Critical Look at Recent Social Policy Reform in Europe from a Gender and Family Perspective', Social Politics, 18: 1, 1-23.

Daly, M. and Scheiwe, K. (2010), 'Individualisation and personal obligations - social policy, family policy, and law reform in Germany and the UK', International Journal of Law, Policy and Family, 24, 2, 177-197.

Donegan, B., George, C., Gilles, A. et al. (2013), Welfare benefits and tax credits handbook, London: Child Poverty Action Group.

Esping-Andersen, G. (1990), The Three Worlds of Welfare Capitalism, Cambridge: Polity Press.

Esping-Andersen, G., Gallie, D., Hemerijk, A. and Myles, J. (2002), Why we need a New Welfare State, Oxford: Oxford University Press.

Frericks, P. (2013), 'Strengthening market principles in welfare institutions: How hybrid pension systems impact on social-risk spreading', Journal of Social Policy, 42, 4, 665-683.

Frericks, P., Jensen, P.H. and Pfau-Effinger, B. (2014), 'Social rights and employment rights related to family care: Family care regimes in Europe', Journal of Aging Studies, 29, 66-77.

Gilbert, N. and Van Voorhis, R. (2003), Changing Patterns of Social Protection, New Brunswick/London: Transaction Publishers.

INPS (2014), http://www.inps.it/portale/default.aspx?itemdir=5804 (accessed 11 February 2016).

ISSA (International Social Security Association) (2014), Social Security Programs Throughout the World: Europe, 2014, Geneva.

Korpi, W. (2010), 'Class and gender inequalities in different types of welfare states: the Social Citizenship Indicator Program (SCIP)', International Journal of Social Welfare Supplement, $19,14-24$.

Leitner, S. (2003), 'Varieties of familialism. The caring function of the family in comparative perspective', European Societies, 5, 4, 353-375.

Lister, R. (2003), Citizenship. Feminist Perspective, New York: University Press.

Marshall, T. (1950), Citizenship and Social Class and other Essays, Cambridge.

MISSOC (2014), Comparative Tables Database: table X (Unemployment) and XI (Guaranteed minimum resources), http://www.missoc.org (accessed 11 February 2016).

Nullmeier, F. (2006), 'Personal Responsibility and its Contradiction in Terms', German Policy Studies, 3, 3, 386-399.

Pfau-Effinger, B. (2004), 'Historical paths of the male breadwinner family model - explanation for cross-national differences', British Journal of Sociology, 55, 3, 177-199.

Republic of Estonia - Social Insurance Board (2014), http://www. sotsiaalkindlustusamet.ee/?lang=en (accessed 11 February 2016).

Saraceno, C. and Keck, W. (2010), 'Can we identify intergenerational policy regimes in Europe?', European Societies, 12, 5, 675-696.

Schnell, R., Hill, P. and Esser, E. (2005), Methoden der empirischen Sozialforschung, München: Oldenbourg.

State Pension Insurance Act - Riigi Teataja, passed 05.12.2001. RT I 2001, 100. 648, Entry into force 01.01.2002, https://www.riigiteataja.ee/en/eli/504072014011/consolide (accessed 11 February 2016).

Walker, R. (2005), Social security and welfare: Concepts and comparisons, Maidenhead: Open University Press.

Weber, Max (1973), 'Die „Objektivität“ sozialwissenschaftlicher und sozialpolitischer Erkenntnis', in Weber, Gesammelte Aufsätze zur Wissenschaftslehre, Tübingen: J.C.B. Mohr (Paul Siebeck), 146-214. 